\title{
Methyl Salicylate Level Increase in Flax after Fusarium oxysporum Infection Is Associated with Phenylpropanoid Pathway Activation
}

\author{
Aleksandra Boba ${ }^{1 \dagger}$, Kamil Kostyn ${ }^{1 * \dagger}$, Anna Kostyn ${ }^{2}$, Wioleta Wojtasik ${ }^{1,3}$, \\ Mariusz Dziadas ${ }^{4}$, Marta Preisner ${ }^{1}$, Jan Szopa ${ }^{1,3}$ and Anna Kulma ${ }^{1 *}$ \\ ${ }^{1}$ Faculty of Biotechnology, University of Wrocław, Wrocław, Poland, ${ }^{2}$ Department of Genetics, Institute of Genetics and \\ Microbiology, University of Wroclaw, Wroclaw, Poland, ${ }^{3}$ Department of Genetics, Plant Breeding and Seed Production, \\ Faculty of Life Sciences and Technology, Wroclaw University of Environmental and Plant Sciences, Wroclaw, Poland, \\ ${ }^{4}$ Department of Food Science and Dietetics, Medical University of Wroclaw, Wroclaw, Poland
}

\section{OPEN ACCESS}

Edited by:

Mary C. Wildermuth,

University of California, Berkeley, USA

Reviewed by:

Hans Thordal-Christensen

University of Copenhagen, Denmark

Corina Vlot,

Helmholtz Zentrum München

Germany

${ }^{*}$ Correspondence:

Kamil Kostyn

kamil.kostyn@uwr.edu.pl

Anna Kulma

kulma@ibmb.uni.wroc.p

${ }^{\dagger}$ These authors have contributed equally to this work.

Specialty section

This article was submitted to

Plant Biotic Interactions,

a section of the journal

Frontiers in Plant Science

Received: 13 September 2015 Accepted: 08 December 2016

Published: 20 January 2017

Citation:

Boba A, Kostyn K, Kostyn A, Wojtasik W, Dziadas M, Preisner M Szopa J and Kulma A (2017) Methyl Salicylate Level Increase in Flax after

Fusarium oxysporum Infection is Associated with Phenylpropanoid Pathway Activation

Front. Plant Sci. 7:1951. doi: 10.3389/fpls.2016.01951
Flax (Linum usitatissimum) is a crop plant valued for its oil and fiber. Unfortunately, large losses in cultivation of this plant are caused by fungal infections, with Fusarium oxysporum being one of its most dangerous pathogens. Among the plant's defense strategies, changes in the expression of genes of the shikimate/phenylpropanoid/benzoate pathway and thus in phenolic contents occur. Among the benzoates, salicylic acid, and its methylated form methyl salicylate play an important role in regulating plants' response to stress conditions. Upon treatment of flax plants with the fungus we found that methyl salicylate content increased (4.8-fold of the control) and the expression profiles of the analyzed genes suggest that it is produced most likely from cinnamic acid, through the $\beta$-oxidative route. At the same time activation of some genes involved in lignin and flavonoid biosynthesis was observed. We suggest that increased methyl salicylate biosynthesis during flax response to $F$. oxysporum infection may be associated with phenylpropanoid pathway activation.

Keywords: flax, Fusarium oxysporum, benzoate, salicylic acid, phenylpropanoids

\section{INTRODUCTION}

Flax (Linum usitatissimum) is a crop plant utilized in many branches of industry as it is a source of oil and fiber, as well as the secondary products-seedcakes and shives. The flax raw products are applied in the food, medical, clothing, cosmetic, chemical, and building industries to name only the most important. Among the advantages of flax is virtually complete utilization of the plant, thus rendering it a zero-waste crop. Unfortunately, the cultivation of flax is stymied because of pathogens, with Fusarium causing the most losses. It is estimated that the flax crop loss caused by this genus of pathogenic fungi reaches 20\% (Muir and Westcott, 2003; Heller et al., 2006). Although Fusarium fungi are mostly soil saprophytes, some species/strains are belligerent toward plants. Fusarium oxysporum $f$.sp. lini is a flax-specific pathogen and is considered the most dangerous species for flax. It invades the plant through roots to spread inside the vascular bundles, where it develops microconidia that after germination block the water and nutrient flow, leading to plant wilt, yellowing of lower parts and death (Olivain et al., 2003; Michielse and Rep, 2009), which is why it is included among necrotrophic pathogens. Sometimes the fungus is called a hemibiotroph, 
because infection initially resembles that of a pathogen that relies on a living host (biotrophic), but eventually transition to killing and consuming host cells (necrotrophic) occurs (Krol et al., 2015). The fungus produces mycotoxins and enzymes hydrolysing cell wall components (cellulases, pectinases, glucuronidases, etc.) that facilitate host tissue penetration.

Plants have developed a number of mechanisms to counteract fungal attack, including passive mechanical barriers (cuticle, cell wall, stomatal apertures, lenticels) and chemical compounds (defensins, phytoanticipins), as well as active defenses (oxidative burst, cell wall reinforcement, antioxidants, phytoalexins, pathogen-related proteins). Upon infection, the plant employs a number of secondary metabolites in the defense against the pathogen. Among them phenolic compounds (phenolic acids, flavonoids, lignin, catecholamines, and benzoic derivatives) are known to play a role in many aspects of the plant's antifungal response (Lattanzio et al., 2006; Kostyn et al., 2012). Their biosynthesis starts in the shikimate pathway, which leads to production of phenylalanine-the first compound on the phenylpropanoid biosynthesis pathway (Figure 1). Non-oxidative deamination of phenylalanine catalyzed by phenylalanine ammonia lyase (PAL), the key-enzyme of this pathway, leads to cinnamic acid, which can be further transformed to $p$-coumaric acid by cinnamic acid 4-hydroxylase $(\mathrm{C} 4 \mathrm{H})$. The above-described core route is branched at several points, and each of the branches leads to a different group of compounds.

The benzoic acid derivatives, including salicylic acid, are produced in two different ways (Chen et al., 2009; Widhalm and Dudareva, 2015). In the first one, chorismic acid is transformed by isochorismate synthase (ICS) to isochorismate and then to salicylic acid (Garcion et al., 2008; Dempsey et al., 2011). It is likely that similar to the bacterial pathway, plants may convert isochorismate to salicylic acid via an isochorismate pyruvate lyase (IPL) enzyme. In Arabidopsis thaliana ics mutants salicylic acid synthesis induced by pathogen treatment was only $5-10 \%$ of that in the control with minimal induced SA made in a double ics1ics 2 mutant (Garcion et al., 2008). In the second way, cinnamic acid is converted to cinnamoyl-CoA by 4-coumarate-CoA ligase $(4 \mathrm{CL})$ in a non-oxidative route (Klempien et al., 2012) or by cinnamate-CoA ligase (CNL) in a $\beta$-oxidative route. The latter, which occurs in peroxisomes is followed by production of benzylCoA, catalyzed by $\beta$-ketothiolase, and further its conversion to benzoic acid. However, the gene or enzyme responsible for conversion of benzoic acid to salicylic acid has not been definitively identified. In a cytoplasmic non-oxidative route, cinnamoyl-CoA can also be converted to benzaldehyde, and then by benzaldehyde dehydrogenase (BALD) to benzoic acid, which is a precursor of salicylic acid. Methyl salicylate is a transport form of salicylate produced by benzoic acid/salicylic acid methyltransferase (BSMT) (Bonnemain et al., 2013; Russell et al., 2016).

$p$-Coumaric acid or its conjugate with coenzyme $\mathrm{A}$, which is formed by 4-coumarate-CoA ligase, can be transformed to other phenolic acids or the phenolic acid-CoA conjugates, respectively. Hydroxycinnamoyl-CoA:quinate/shikimate hydroxycinnamoyl transferase (HCT) is considered the key enzyme in subsequent phenolic acid biosynthesis. They may serve in biosynthesis of many different compounds, including lignins-one of the cell wall polymers-with assistance of $\mathrm{H}_{2} \mathrm{O}_{2}$, peroxidases and possibly dirigent proteins (Hatfield, 2001; Mandal et al., 2011). Though ferulic acid is involved in lignin biosynthesis, it can also be a substrate in vanillin and further vanillic acid synthesis. The lignin biosynthesis route within the phenylpropanoid pathway diverges from other main route of flavonoid biosynthesis. Flavonoids are a large and very diversified group of phenolic derivatives of many various functions, including participation in plant reaction to abiotic and biotic stresses. Many flavonoids exists in the cell in form of glycosides, which have increased solubility and stability.

Benzenoid compounds participate in the plant's response to environmental stress either through their direct anti-microbial activity (Kocacaliskan et al., 2006), antioxidative properties (Dai and Mumper, 2010; Velika and Kron, 2012) or, in the case of salicylic acid, involvement in signaling pathways. After penetration of plant tissue by microbial pathogens, pathogenassociated molecular patterns (PAMPs), which generally are highly conserved molecules within a class of microbes that have an essential function in microbial fitness or survival [e.g., chitin, $\beta$-(1,3)-glucan], are recognized by specific receptors, which activate a number of defenses (PAMP-triggered immunity-PTI) (Zipfel and Robatzek, 2010). PTI can be suppressed by pathogen effectors, thus leading to successful colonization of the host. However, this can be repressed if the plant expresses a resistance protein $(\mathrm{R})$ that recognizes the effector to induce effectortriggered immunity (ETI). During PTI and ETI various defense responses are activated. Salicylic acid (SA) is an important endogenous plant hormone signal in delivering the extracellular PAMP message into the plant cell to initiate the transcription of defense genes, including production of reactive oxygen species (ROS), and increased expression of pathogenesis-related $(P R)$ genes (Tsuda et al., 2008; Vlot et al., 2009; Muthamilarasan and Prasad, 2013), as well as long-lasting, ample resistance to subsequent pathogen infection known as systemic acquired resistance (SAR) (Ali and Reddy, 2008). Salicylic acid (SA) is recognized a key signal for the activation of disease resistance in many plant species. Infection signal spreading, both to the healthy tissues of the infected plant or other neighboring plants occurs (in part) via a biologically inactive form of SA-methyl salicylate. After reaching its destination, this volatile molecule is converted back to SA thanks to the esterase activity of salicylic acid-binding protein 2 (SABP2) (Park et al., 2007).

Phenylpropanoid secondary metabolites also greatly contribute to plant pathogen resistance (Daayf et al., 2012). Several phenolic acids possess high antifungal activity. Ferulic acid was shown to suppress growth of Fusarium verticillioides and Fusarium proliferatum (Ferrochio et al., 2013) and inhibit the biosynthesis of Fusarium mycotoxins (Boutigny et al., 2009). Accumulation of phenolic compounds at the infection site also reinforces the cell wall, which is accompanied by localized production of ROS driving cell wall cross linking (Field et al., 2006). Biosynthesis of lignin, which contribute to the natural barrier against pathogens, is based on phenolic acids. In addition, phenolic acids and other phenylpropanoids (flavonoids) possess 


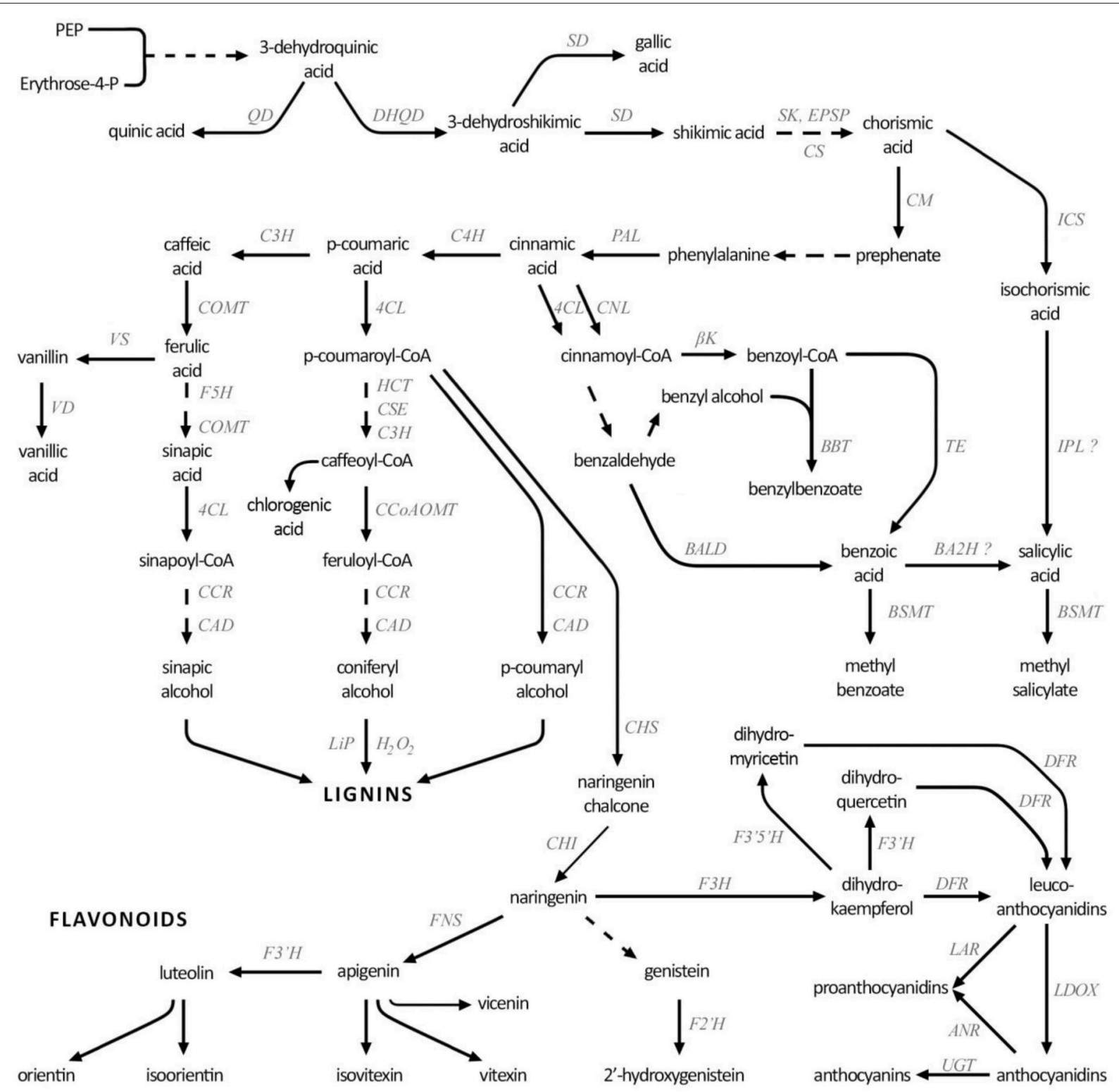

FIGURE 1 | Simplified phenolic compound biosynthesis pathway. DHQD, 3-dehydroquinate dehydratase; QD, quinate dehydrogenase; SD, shikimate dehydrogenase; EPSP, 3-phosphoshikimate 1-carboxyvinyltransferase; SK, shikimate kinase; CS, chorismate synthase; CM, chorismate mutase; ICS, isochorismate synthase; IPL, isochorismate pyruvate lyase; PAL, phenylalanine ammonia lyase; $\mathrm{C} 4 \mathrm{H}$, cinnamic acid 4-hydroxylase; 4CL, 4-coumarate-CoA ligase; CNL, cinnamate-CoA ligase; $\beta \mathrm{k}, \beta$-ketothiolase; TE, thioesterase; BALD, benzaldehyde dehydrogenase; BBT, benzyl alcohol O-benzoyltransferase; BA2H, benzoic acid 2-hydroxylase; BSMT, benzoic acid/salicylic acid methyltransferase; COMT, caffeic acid 3-O-methyltransferase; VS, vanillin synthase; VD, vanillin dehydrogenase; HCT, hydroxycinnamoyl-CoA:quinate/shikimate hydroxycinnamoyl transferase; CSE, caffeoyl shikimate esterase; C3H, 4-coumarate 3-hydroxylase; CCOAOMT, caffeoyl-CoA O-methyltransferase; F5H, ferulate 5-hydroxylase; CCR, cinnamoyl-CoA reductase; CAD, cinnamyl-alcohol dehydrogenase; LiP, lignin peroxidase; CHS, chalcone synthase; $\mathrm{CHI}$, chalcone isomerase; F3H, flavanone 3-dioxygenase; FNS, flavone synthase; $\mathrm{F} 3^{\prime} \mathrm{H}$, flavonoid-3'-hydroxylase; $\mathrm{F} 3^{\prime} 5^{\prime} \mathrm{H}$, flavonoid $3^{\prime}, 5^{\prime}$-hydroxylase; DFR, dihydroflavonol reductase; LAR, leucoanthocyanidin reductase; LDOX, eucoanthocyanidin dioxygenase; ANR, anthocyanidin reductase; UGT, UDP-glucuronosyltransferase.

significant antioxidant properties (Khanam et al., 2012), and they significantly contribute to quenching of free radicals produced during the oxidative burst. This "extinguishing" of the initial plant response is important for example in the cases when some necrothrophs induce ROS production in the infected tissue to induce cell death that facilitates subsequent infection
(Govrin and Levine, 2000). Flavonoids are involved in the inhibition of pathogen enzymes. It was shown that the antipathogenic effect of flavonoids depends on their structure. It was reported that the strongest antifungal activity is demonstrated by unsubstituted flavones and unsubstituted flavanones (Mierziak et al., 2014a). 
The aim of this study was to evaluate the engagement of different branches of the shikimic acid/phenylpropanoid pathway in the early response of flax to F. oxysporum attack. As the shikimate/phenylpropanoid pathway produces a variety of compound species (benzoates, phenolic acids, lignin, flavonoids, etc.), their mutual relationships, ratios and interactions are of the highest relevance to the process of plant early stages of antifungal response. Our investigation of the transcript levels of genes involved in phenolic biosynthesis as well as the changes of phenolic compound levels has broadened the knowledge of its involvement in flax pathogen resistance.

\section{MATERIALS AND METHODS}

\section{Plant Material}

Flax seeds (L. usitatissimum cv. Nike) were obtained from the Flax and Hemp Collection of the Institute of Natural Fibres in Poland. The seeds were germinated on Petri dishes containing Murashige and Skoog medium (Sigma-Aldrich) supplemented with $1 \%$ sucrose and solidified with $0.9 \%$ agar, under a $16 \mathrm{~h}$ light $\left(21^{\circ} \mathrm{C}\right), 8 \mathrm{~h}$ darkness $\left(16^{\circ} \mathrm{C}\right)$ regime.

\section{Infection Tests}

F. oxysporum was grown for 4 days at $18^{\circ} \mathrm{C}$ on potato/ dextrose/agar (PDA) medium (Sigma- Aldrich). Fourteen dayold flax seedlings grown on MS medium were transferred, together with the medium, onto a PDA medium with F. oxysporum. PDA without fungus was used for a control. The flax seedlings were then collected after $6,12,24,36$, and $48 \mathrm{~h}$ and immediately frozen in liquid nitrogen and stored at $-76^{\circ} \mathrm{C}$ before further experiments. The experiment was performed in three biological repeats. The whole experimental approach was then repeated and gave similar results.

\section{Identification of cDNA Sequences}

Unknown cDNA sequences of the flax genes of interest were identified based on homology alignments with the known gene sequences from other plant species(Clustal Omega, http://www. ebi.ac.uk/Tools/msa/clustalo/). The sequences were amplified in PCR reaction, where cDNA reverse transcribed from mRNA isolated from 14 day-old flax seedlings was used as a template. The primers were designed for the most homologous regions. The reaction product was analyzed via gel electrophoresis and after extraction from the gel using a DNA Gel-out Kit, it was cloned with a TOPO TA Cloning Kit (Invitrogen) and sequenced (Genomed SA, Poland). For verification the obtained DNA sequences were compared with the flax genome sequence (L. usitatissimum cv. Bethune) and aligned with corresponding genes from other plants in the GenBank database (http://www. ncbi.nlm.nih.gov/blast/).

\section{Analysis of Gene Transcript Levels}

Total RNA was isolated with the Trizol (Invitrogen) method according to the producer's protocol. The co-isolated DNA was removed by treatment with DNase I. The RNA was then used for genetranscript level analysis. It was transcribed to cDNA with a High Capacity cDNA Reverse Transcription Kit
(Applied Biosystems), which was used in real time PCR (RTPCR) technique using a DyNAmo SYBR Green qPCR Kit (Thermo Scientific) on the StepOnePlus ${ }^{\mathrm{TM}}$ Real-Time PCR System (Applied Biosystems) in triplicates. The conditions for the reactions were chosen in accordance with the producer's instructions. The primers were designed and are presented in Supplementary Table S1. For reference the actin gene was used. The differences in levels of transcripts were presented as relative quantification (RQ) to the reference gene and are presented in Supplementary Figure S1.

The isolated RNAs from tissue samples collected at 24 and $48 \mathrm{~h}$ after infection were also submitted to sequencing. Necessary sample preparations, sequencing and data processing was performed by an outsourcing company (Genomed SA, Poland). For both qRT-PCR and RNA_Seq, data from three biological replicates was analyzed.

After sequencing, the obtained transcript sequences were then aligned with the identified flax gene sequences of interest (Clustal Omega http://www.ebi.ac.uk/Tools/msa/clustalo/) and only transcripts with open reading frame, of which expression was higher than 2-fold or less than 0.5-fold (statistically significant at $p$-value $\leq 0.001$ ) were further considered. Such sequences were used for phylogenetic tree preparation using the online ClustalW2 Phylogeny software (http:// www.ebi.ac.uk/Tools/phylogeny/clustalw2_phylogeny/, Dist. Corr $=$ off, Excl. Gaps = off, Clust. Meth. = Neighbour-joining, P.I.M. = off) and are presented in Supplementary Table S2. Sequences of the transcripts can be found in Supplementary Table S3.

\section{Determination of Phenolic Compound Contents}

Plant tissue collected after F. oxysporum infection tests was used for the determination of phenolic contents. $50 \mathrm{mg}$ of the frozen tissue was ground in liquid nitrogen and extracted with $0.1 \% \mathrm{HCl}$ in methanol followed by $15 \mathrm{~min}$ in ultrasonic bath incubation. The samples were centrifuged $\left(12,000 \mathrm{~g}, 4^{\circ} \mathrm{C}, 10 \mathrm{~min}\right)$ and the supernatant was collected. The procedure was repeated twice, the supernatants were combined and then dried under nitrogen flow. The resulting pellet was re-suspended in $200 \mu \mathrm{l}$ methanol and used in analysis of free metabolite contents. The remaining tissue after methanol extraction was used subjected to alkaline hydrolysis $\left(2 \mathrm{M} \mathrm{NaOH}\right.$ at $37^{\circ} \mathrm{C}$, overnight). After adjusting $\mathrm{pH}$ to 3 with concentrated $\mathrm{HCl}$, two volumes of ethyl acetate were added and mixed. The mixture was then centrifuged at 12,000 $\times \mathrm{g}, 4^{\circ} \mathrm{C}$ for $15 \mathrm{~min}$. The ethyl acetate phase was collected. The extraction to ethyl acetate was repeated twice. The collected ethyl acetate volumes were combined and dried under nitrogen flow and re-suspended in $200 \mu \mathrm{l}$ of methanol and then the samples were used for the determination of cell wall bound metabolite contents.

The methanol extracted and alkali-hydrolyzed samples were next analyzed with a Waters Acquity UPLC system with a 2996 PDA QTOF mass detector on an Acquity UPLC BEH C18 $(2.1 \times 100 \mathrm{~mm}, 1.7 \mu \mathrm{m})$ column. The mobile phase was passed through the column at a flow rate of $0.4 \mathrm{ml} / \mathrm{min}$. The mobile phase consisted of the following components: Solvent A, 0.1\% 
formic acid; and solvent B, 100\% acetonitrile. For the first minute, isocratic elution was carried out using $95 \%$ of A in B. From 2 to $12 \mathrm{~min}$, a linear gradient was applied using 95 to $70 \%$ of $\mathrm{A}$ in B. From 13 to $17 \mathrm{~min}$, a linear gradient was applied using 70 to $0 \%$ of $\mathrm{A}$ in $\mathrm{B}$. In the final minute concentration of $\mathrm{A}$ returned to $95 \%$. The column was kept at $25^{\circ} \mathrm{C}$. A photodiode array (PDA) was used to detect absorption between 210 and $500 \mathrm{~nm}$. The MS spectra were recorded in ESI positive mode for $17 \mathrm{~min}$ in the 50-800 Da range. The parameters were: Nitrogen flow: 800 $\mathrm{L} / \mathrm{h}$, source temperature: $70^{\circ} \mathrm{C}$, desolvation temperature cone: $400^{\circ} \mathrm{C}$, capillary voltage: 3.50 , sampling cone: 30 , cone voltage: Ramp 40-60 V, scan time: $0.2 \mathrm{~s}$. The identities of components were determined based on either their retention times, UV and mass spectra comparison to authentic standards (Sigma-Aldrich, USA) or for compound derivatives (including glycosides) - based on UV and MS spectra.

\section{Determination of Salicylic Acid and Methyl Salicylate Contents}

$5 \mathrm{~g}$ of frozen tissue was ground in liquid nitrogen and extracted with methanol chloroform (8:2) for $1 \mathrm{~h}$ at room temperature (on shaker), $50 \mathrm{ng}$ of mandelic acid was added as an internal standard to each sample, then centrifuged (10 min, 12,000 g). The supernatants were collected and evaporated under nitrogen flow. The residues were supplemented with $200 \mu \mathrm{l}$ of BSTFA:TMCS 9:1, vortexed for $1 \mathrm{~min}$ and incubated at $120^{\circ} \mathrm{C}$ for $60 \mathrm{~min}$. (Huang et al., 2015). After derivatization, sample was vigorously mixed and injected directly to GC/MS. A Shimadzu QP-2020 gas chromatograph coupled with single quadrupole mass spectrometer system (Shimadzu, Japan) was used in electron impact (EI) with electron energy $70 \mathrm{eV}$. Samples were separated by use of a $30 \mathrm{~m} \times 0.25 \mathrm{~mm} \times 0.25 \mu \mathrm{m}$ film thickness ZB-5MSi capillary column from Phenomenex, USA. Samples $(1 \mu \mathrm{l})$ was inject in split mode $(1: 10)$. Oven program was set to $40^{\circ} \mathrm{C}$ for $0 \mathrm{~min}$ hold then increased at $20^{\circ} \mathrm{C} / \mathrm{min}$ rate to $300^{\circ} \mathrm{C}$ for $5 \mathrm{~min}$ hold (total time 18.00). Helium $(99,9999 \%)$ was used as mobile phase with linear velocity of $36.1 \mathrm{~cm} / \mathrm{s}$, total flow $14 \mathrm{ml} / \mathrm{min}$. Mass spectrometer was used in SIM mode monitoring 5 channels: 267, 209, 179, 147, 253 from $5.00 \mathrm{~min}$ to $18.00 \mathrm{~min}$ at 10,000 scans/s. Temperature of transfer line was $300^{\circ} \mathrm{C}$ and ion source $220^{\circ} \mathrm{C}$. Contents of salicylic acid and methyl salicylate were determined based on original standards (Sigma-Aldrich, USA). We were unable to detect salicylic acid glucosides (TransMIT $\mathrm{GmbH}$, Germany) in the studied samples.

\section{Determination of Lignin Content}

Total lignin content was determined by the acetyl bromide method (Iiyama and Wallis, 1990). Briefly, $100 \mathrm{mg}$ of flax seedling tissue was heated at $100^{\circ} \mathrm{C}$ for $2 \mathrm{~h}$. Then, $10 \mathrm{ml}$ of $\mathrm{H}_{2} \mathrm{O}$ was added and the samples were heated at $65^{\circ} \mathrm{C}$ for an additional hour with mixing every $10 \mathrm{~min}$. The samples were filtered through GF/A $24 \mathrm{~mm}$ filters (Whatman) and the filtrates were washed three times with $\mathrm{H}_{2} \mathrm{O}$, ethanol, acetonitrile, and diethyl ether in that order. The filters were then placed in glass vials and heated at $70^{\circ} \mathrm{C}$ overnight. Subsequently, $2.5 \mathrm{ml}$ of $25 \%$ (v/v) acetyl bromide in $80 \%$ acetic acid were added and the samples were incubated at $50^{\circ} \mathrm{C}$ for $2 \mathrm{~h}$. The samples were then cooled down and 10 $\mathrm{ml}$ of $2 \mathrm{M} \mathrm{NaOH}$ and $12 \mathrm{ml}$ of $80 \%$ acetic acid were added. After overnight incubation, the lignin content was determined spectrophotometrically at $\lambda=280 \mathrm{~nm}$. Coniferyl alcohol was used for standard curve preparation. The assays were prepared in three biological repetitions.

\section{Determination of Cellulose Content}

Cellulose content was determined with the anthrone method described by Ververis et al. (2004). Plant tissue (100 mg) was ground in liquid nitrogen and incubated with a mixture of $65 \%$ nitric acid and $80 \%$ acetic acid (1:8 vol.) with heating at $100^{\circ} \mathrm{C}$ for $1 \mathrm{~h}$. After that the samples were centrifuged [ $5 \mathrm{~min}, 12,000$ $\times \mathrm{g}$, room temperature $(\mathrm{RT})]$ and the pellet was washed with water twice, dissolved in $1 \mathrm{ml}$ of $67 \% \mathrm{H}_{2} \mathrm{SO}_{4}(\mathrm{v} / \mathrm{v})$ and incubated at $\mathrm{RT}$ for $1 \mathrm{~h}$ with shaking. Then the samples were diluted and $100 \mu \mathrm{l}$ were added to $900 \mu \mathrm{l}$ of cooled $0.2 \%$ anthrone in $67 \% \mathrm{H}_{2} \mathrm{SO}_{4}$, mixed and heated at $100^{\circ} \mathrm{C}$ for $15 \mathrm{~min}$. Next the samples were cooled down and the level of cellulose was detected spectrophotometrically at $620 \mathrm{~nm}$. Commercial cellulose (SigmaAldrich, USA) was used for standard curve preparation. The assays were prepared in three biological repetitions.

\section{Assessment of Influence of Selected Phenolic Compounds on Fusarium oxysporum Growth}

In order to determine the direct influence of selected phenolic compounds on the growth of $F$. oxysporum, PDA media supplemented with standard solutions of salicylic acid, vanillin, vanillic acid, $p$-coumaric acid, caffeic acid, ferulic acid, orientin, isoorientin, vitexin, and isovitexin in three concentrations (100, $50,10 \mu \mathrm{M})$ were prepared. PDA medium with appropriate amounts of the solvent, in which the standard compounds were dissolved, were used for the control. F. oxysporum mycelium fragments were grown for $48 \mathrm{~h}$ on Petri dishes with the media prepared in this way. Next the mycelia were photographed and their surfaces were measured.

\section{Statistical Analysis}

Statistical analyses were performed using Statistica 10 software (StatSoft, USA). The significance of differences between the means was determined using Student's $t$-test for independent samples. The significance of differences in transcript level after RNA sequencing were determined with Fisher's exact test.

\section{RESULTS}

\section{Transcript Levels of Selected Genes of Shikimate/Phenylpropanoid/Benzoate Pathway in Flax after Fusarium oxysporum Treatment}

The initial screening of the shikimate/phenylpropanoid gene expression in 2 week old flax seedlings treated with F. oxysporum by means of qRT-PCR method revealed substantial alterations in the expression pattern (Supplementary Figure S1). As several of those genes have several isoforms, we performed transcriptome sequencing to obtain a broader and more detailed image 
of the changes observed in our initial experiment. Several transcript sequences with homology to the genes connected with phenolic compound synthesis were found after whole transcriptome sequencing of RNA isolated from flax plants after 24 and 48 h post infection with F. oxysporum (hpi). The results were obtained based on three biological replicates. The genes were divided into groups according to the route they participate in. Whole transcriptome data analysis allowed for the determination of transcript levels. Only transcripts with open reading frame, homologous to the investigated genes, whose expression was more than 2-times higher or less than 2 -times lower (statistically significant at $p$-value $\leq 0.001$ ) were considered (Table 1). Transcripts of genes involved in the core route of the shikimate/phenylpropanoid pathway were generally more abundant at $24 \mathrm{hpi}$, with the highest increase measured for $P A L$ (up to 8.21-fold of the control). At 48 hpi the activation of these genes receded. Only for shikimate dehydrogenase gene $(S D)$, transcript levels were considerably lower at 48 hpi compared to the control. Increase of transcript levels of three genes of benzoate route: 3-ketoacyl-CoA thiolase 2 ( $\beta$-ketothiolase), benzoate/salicylate carboxymethyltransferase $(B S M T)$, and benzyl alcohol O-benzoyltransferase (BBT), was measured. The BSMT gene activation is especially worthy of note. Abundance of transcripts of this gene reached 9.1- and 18.8-fold of the control at 24 and $48 \mathrm{hpi}$, respectively. Genes of lignin biosynthesis route were up-regulated at $24 \mathrm{hpi}$, but this activation subsided and even decreases in transcript levels compared to the control were observed at $48 \mathrm{hpi}$. Increased transcription of genes involved in flavonoid biosynthesis was observed both at 24 and 48 hpi. Considerable activation of the key gene of this pathwaychalcone synthase (CHS) (up to 75-fold of the control) was noted at $48 \mathrm{hpi}$. Activation of leucoanthocyanidin dioxygenase (LDOX) gene at $24 \mathrm{hpi}$ (76.6-fold of the control) and at $48 \mathrm{hpi}$ (up to 13.5fold of the control) was observed, while expression of ANR gene, involved in flavanol and non-hydrolysable tannin biosynthesis was down-regulated both at 24 and 48 hpi.

\section{Metabolite Changes in Flax after Fusarium oxysporum Treatment}

We investigated whether the changes in gene transcript levels after F. oxysporum treatment were reflected in corresponding metabolite contents. Therefore, methanol extracts (free metabolites) and extracts of cell wall bound compounds (released after alkaline hydrolysis) from plants at 24 and $48 \mathrm{~h}$ after treatment with $F$. oxysporum were analyzed with the UPLC-MS technique. For salicylic acid and methyl salicylate contents GC-MS method was employed (Table 2).

Among the free metabolites a significant increase in methyl salicylate content (4.8-fold of the control) was observed at 48 hpi. No significant changes in the level of its precursor, salicylic acid were measured. The remaining metabolites in the soluble metabolite extracts could be divided into two groups: Phenolic acids and flavonoids. Content of caffeic acid derivative - the most abundantly represented phenolic acid decreased by 15.5 and $21.7 \%$ at 24 and 48 hpi, respectively. Also, levels of chlorogenic acids dropped down at both studied time points after infection (by 27.1 to $48.9 \%$ ). Ferulic acid content increased both at 24 and 48 hpi, by 22.7 and 59.86\%, respectively. Total flavonoid content increase was observed, by 36.2 and $77.1 \%$ at 24 and 48 hpi, respectively. Vicenin was found to be the most abundant compound of this type, and it increased by 68.8 and $121 \%$ at 24 and 48 hpi, respectively. Contents of isovitexin and one of apigenin diglycosides increased at 48 hpi by 53.4 and $38.6 \%$. Decrease in the contents of quercetin diglycoside and one of apigenin diglycosides ranged from 9.3 to $21.7 \%$ below the control. Among cell wall bound compounds p-coumaric acid content was shown to be dropped down by $40.7 \%$ at 24 hpi compared to the control, while its derivative level increased by $82.4 \%$ at 48 hpi. Content of ferulic acid decreased by 36.7 and $20.2 \%$ below the control, at 24 and $48 \mathrm{hpi}$, respectively. A $23.2 \%$ decrease in 4 -hydroxybenzaldehyde at 24 hpi was measured. An independent experimental approach gave similar results (data not included).

Lignin and cellulose contents in flax after Fusarium treatment were measured. For lignin, a decrease by $17 \%$ and for cellulose an increase by $21 \%$ was observed in plants at 48 hpi relatively to the control.

\section{Influence of Selected Phenolic Compounds on Fusarium oxysporum Growth}

The influence of selected phenolics on growth of F. oxysporum was investigated. The results are presented in Table 3. Most of the used compounds showed an inhibitory effect on fungal growth, though the influence differed according to the concentrations that was used. Among benzoate derivatives the most profound effect was observed for vanillin at 0.1 $\mathrm{mM}$ concentration (0.5-fold of the control). Vanillic acid in concentration of $0.01 \mathrm{mM}$ led to inhibition of F. oxysporum growth to 0.64 -fold of the control. Also, phenolic acids turned to be efficient inhibitors of Fusarium growth, even at low concentrations. Strong growth inhibition was observed for flavonoids, vitexin, and isovitexin, though low concentrations of these compounds did not exert an inhibiting effect on Fusarium growth. Interestingly, $0.05 \mathrm{mM}$ orientin impeded the growth of the fungus, while higher concentration did not exert such an effect.

\section{DISCUSSION}

Flax is an appreciated source of oil and fiber used in many branches of industry, ranging from food, textiles and medicine to chemicals, cosmetics, and construction, but unfortunately it is the target for fungal attacks, with $F$. oxysporum being one of the most dangerous flax-specific pathogens causing the most crop loss. Plants have evolved numerous defense mechanisms against pathogen infections, and even though they have been extensively studied, we still lack knowledge on several aspects of plant resistance. Initiation of a resistance response requires perception of signal molecules, either synthesized by the invading pathogen or released from damaged plant cell walls, which turns on the activation of pre-existing components, as well as generation of active agents, such as ROS (Lehmann et al., 2015). Whether ROS would function as signaling molecules or 
TABLE 1 | Transcript levels of genes of shikimate/phenylpropanoid/benzoate pathway measured in 24 and $48 \mathrm{~h}$ after infection with $F$. oxysporum presented as fold of the non-treated control; "-" symbol stands for no change in the transcript expression or change in the range between 0.5 and 2 -fold of the control.

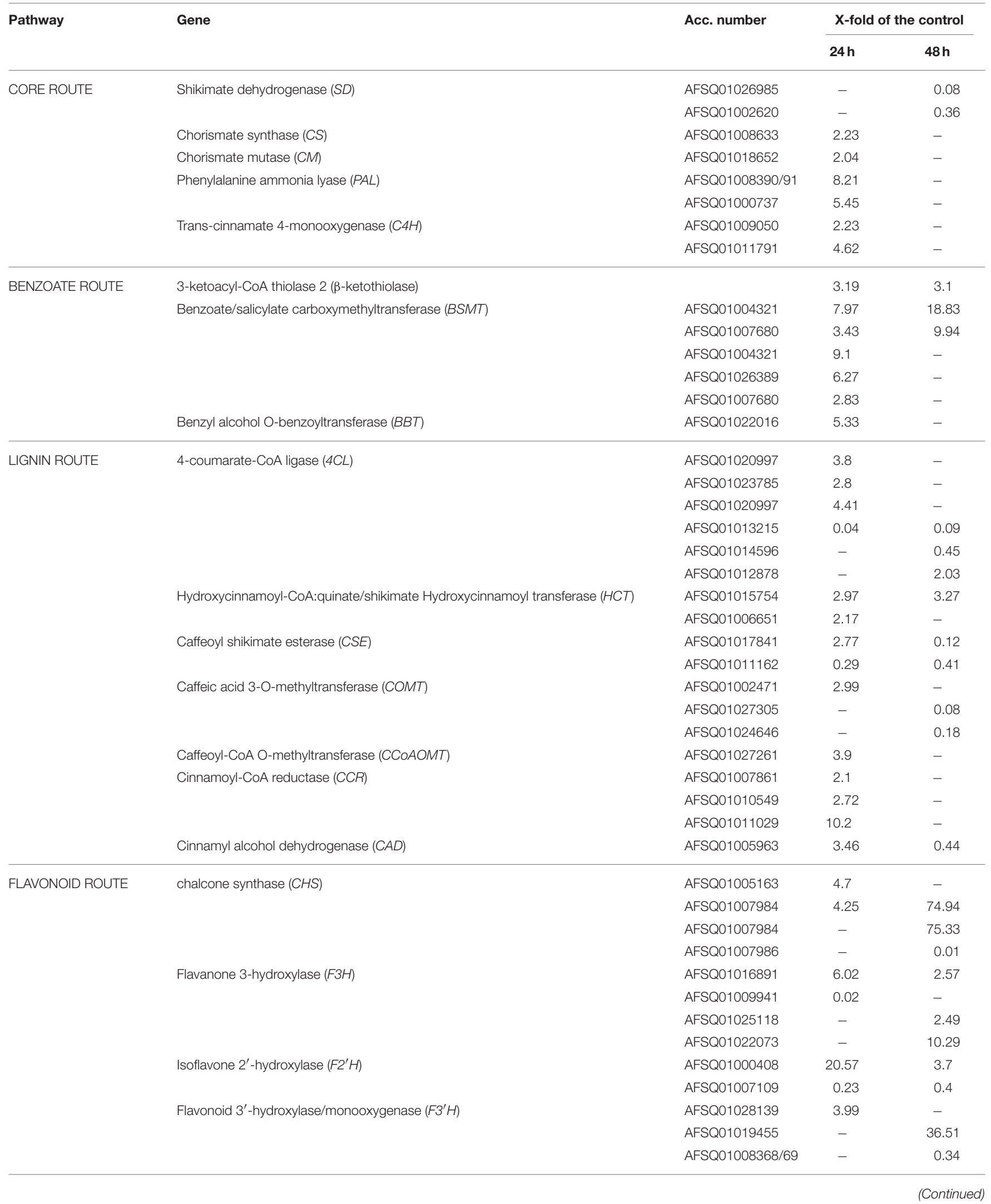




\section{TABLE 1 | Continued}

\begin{tabular}{|c|c|c|c|c|}
\hline \multirow[t]{2}{*}{ Pathway } & \multirow[t]{2}{*}{ Gene } & \multirow[t]{2}{*}{ Acc. number } & \multicolumn{2}{|c|}{$X$-fold of the contro } \\
\hline & & & $24 \mathrm{~h}$ & $48 \mathrm{~h}$ \\
\hline & Flavonoid $3^{\prime}, 5^{\prime}$-hydroxylase $\left(F 3^{\prime}, 5^{\prime} H\right)$ & AFSQ01012300 & 2.34 & - \\
\hline & leucoanthocyanidin dioxygenase (LDOX) & AFSQ01021358 & 76.64 & 13.54 \\
\hline & & AFSQ01012389 & - & 5.11 \\
\hline & Anthocyanidin reductase (ANR) & AFSQ01023196 & 0.36 & 0.27 \\
\hline & Udp-glucosyltransferase (UGT) & AGD95009 & 38.39 & - \\
\hline
\end{tabular}

Presented results are statistically significant at $p<0.001$ and based on three biological replicates. Accession numbers of the sequences of isoforms are provided.

could cause oxidative damage to the tissues depends on the subtle balance between production and scavenging of ROS (Sharma et al., 2012).One of the molecules important for providing this balance is salicylic acid (SA), involved in the regulation of both ROS production and synthesis of antioxidants, mostly derived from the phenylpropanoid pathway (Mandal et al., 2009). Phenylpropanoids possess high antioxidant capacity (Korkina, 2007) and their production occurs relatively early during the plant response to the pathogen (Kostyn et al., 2012). The phenolic derivatives originate from the shikimate pathway. The early genes of this pathway are known to be up-regulated in response to pathogen infection in concert with $P A L$, the key gene in phenolic compound (lignin, benzoates, flavonoids) synthesis (Lazar, 2005). In flax treated with F. oxysporum we have measured high induction of $P A L$ and trans-cinnamate 4-monooxygenase $(\mathrm{C} 4 \mathrm{H})$, the following gene on the pathway, at $24 \mathrm{hpi}$. This in conjunction with the unchanged transcript level of the ICS gene and elevated transcript level of the $\beta$-ketothiolase $(\beta K)$ gene along with unchanged $B A L D$ gene transcript level led us to the suggestion that in flax, at least at early stages of infection activation of oxidative transformation of the cinnamic acid controls SA production manifested as MeSA. These results are in opposition to data from Arabidopsis, where ICS was shown to be a key gene responsible for SA biosynthesis (Wildermuth et al., 2001; Garcion et al., 2008) and from other plants in which the isochorismate pathway is the dominant pathway for induced SA synthesis (Dempsey et al., 2011). However, no increase in SA content was observed in our experiments. This may be due to its immediate processing to its methylated form-methyl salicylate (MeSA). We have observed almost 5 -fold increase in this compound content in the infected seedlings. This correlated well with a considerable activation of benzoate/salicylate carboxymethyltransferase (BSMT) gene, which catalyses the transformation of SA to MeSA (Chen et al., 2003). It was shown before in a number of reports that a reduced $P A L$ gene transcript level correlates with decreased SA levels and increased plant susceptibility to pathogen infection (Huang et al., 2010). It is known that PAL and other genes of the phenylpropanoid pathway (e.g., $4 C L, C H S$ ) are activated upon induction with both fungal and cell wall elicitors (Davis and Hahlbrock, 1987; Lawton and Lamb, 1987; Xue et al., 2014). In elicited flax up-regulation of $P A L$, cinnamoyl-CoA reductase $(C C R)$, and cinnamyl alcohol dehydrogenase $(C A D)$ was reported (Hano et al., 2006; Kostyn et al., 2012). In our study we also observed an increase in the transcript level of genes connected to lignin biosynthesis. Transcript level of chalcone synthase $(\mathrm{CHS})$ gene was elevated at $24 \mathrm{hpi}$ and considerably higher at 48 hpi. Flavonoids can be converted into glucosylated forms by either C-glucosyltransferase or O-glucosyltransferase. Both types of glycosides, which can be derived from apigenin and luteolin, were measured in higher amounts in flax after fungal infection, which corresponds to the increased glucosyltransferase gene transcript level. It is well established that flavonoids have high anti-pathogenic properties (Mierziak et al., 2014b). Overexpression of glucosyltransferase in flax and Arabidopsis was shown to protect plants against infection (Lorenc-Kukula et al., 2009; Shin et al., 2012). In our experiments, the elevation of glucosylated forms of flavonoids was correlated with the transcript level of CHS gene. The observed discrepancy between activation of transcription of lignin route associated genes and the lignin level could be explained by the competition for substrates. It is known that lignin biosynthesis is inversely related to flavonoid production (Laffont et al., 2010). Zuk et al. (2011) reported on decreased lignin content in transgenic flax plants with overproduction of flavonoids. The concept that the flavonoid and lignin routes could be organized as enzyme complexes was first proposed by Stafford (1974) as an explanation of mutual competition for common intermediates. Silencing of hydroxycinnamoyl-CoA:quinate/shikimate hydroxycinnamoyl transferase (HCT) gene expression led to the redirection of the metabolic flux into flavonoids through CHS activity in Arabidopsis (Besseau et al., 2007) and in alfalfa (Gallego-Giraldo et al., 2011a). A similar effect was obtained in plants with a silenced 4-coumarate 3-hydroxylase (C3H) gene (Li et al., 2010). Formation of specific enzyme complexes might force metabolite flux toward flavonoids even in the presence of excess lignin biosynthesis enzymes. In our experiments transcript levels of genes of lignin synthesis were elevated, while we observed decreased levels of lignin accompanied by higher cellulose contents. The other possibility for the lower lignin content may be in fact connected with the pathogen attack itself and digestion of the cell wall (Rodriguez et al., 1996). In such a scenario, release of elicitors from the cell wall would induce SA synthesis directly (Gallego-Giraldo et al., 2011b) or through ROS. It has been reported that the level of salicylic acid (SA) increased after apoplastic $\mathrm{H}_{2} \mathrm{O}_{2}$ bursts mediated by NADPH oxidases and extracellular peroxidases (O'Brien et al., 2012; Mammarella et al., 2015), though in this case a biosynthesis route involving ICS 
TABLE 2 | Contents of free and cell wall bound metabolites in extracts prepared from plants at $48 \mathrm{~h}$ after $\mathrm{F}$. oxysporum treatment (mean values of three biological repeats \pm standard deviations).

Metabolite
Metabolite content

\begin{tabular}{cccc}
\hline \multicolumn{2}{c}{$24 \mathrm{~h}$} & & $48 \mathrm{~h}$ \\
$\begin{array}{c}\text { mean } \\
(\mu \mathrm{g} / \mathrm{g} \mathrm{FW})\end{array}$ & $S D$ & $\begin{array}{c}\text { mean } \\
(\mu \mathrm{g} / \mathrm{g} \mathrm{FW})\end{array}$ & $S D$
\end{tabular}

\section{FREE COMPOUNDS}

Salicylic acid

Salicylic acid

\begin{tabular}{llcccc} 
& F. oxysporum & 0.177 & 0.049 & 0.156 & 0.084 \\
\hline Methyl salicylate & Control & 0.138 & 0.071 & 0.177 & 0.065 \\
& F. oxysporum & 0.075 & 0.081 & $0.744^{\star \star \star}$ & 0.051 \\
\hline 3-O-caffeoylquinic Control & 156.6 & 21.3 & 134.9 & 8.1 \\
acid (chlorogenic & F. oxysporum & $114.1^{*}$ & 18.8 & $68.9^{\star}$ & 21.3
\end{tabular}

acid)

\begin{tabular}{llcccc}
\hline O-caffeoylquinic & Control & 131.2 & 3.2 & 146.4 & 6.8 \\
acid (chlorogenic & F. oxysporum & 144.8 & 15.4 & $81.3^{\star \star \star}$ & 16.5 \\
\hline
\end{tabular}

acid isomer) $\$$

\begin{tabular}{|c|c|c|c|c|c|}
\hline \multirow[t]{2}{*}{ Caffeic acid } & Control & 271.2 & 8.1 & 254.5 & 7.3 \\
\hline & F. oxysporum & 288.7 & 21.6 & 315.12 & 44.8 \\
\hline Caffeic acid & Control & 1413.2 & 27.1 & 1501.4 & 49.1 \\
\hline derivative $\$$ & F. oxysporum & $1193.6^{\star \star \star}$ & 38.2 & $1175.5^{\star \star \star}$ & 14.6 \\
\hline \multirow[t]{2}{*}{ Ferulic acid } & Control & 107.7 & 4.7 & 111.6 & 5.8 \\
\hline & F. oxysporum & $132.2^{\star \star}$ & 3.6 & $178.4^{\star \star \star}$ & 3.8 \\
\hline Ferulic acid & Control & 31.8 & 1.4 & 17.6 & 4.1 \\
\hline derivative $\$$ & F. oxysporum & $25.5^{\star}$ & 3.5 & 28.0 & 11.5 \\
\hline \multirow[t]{2}{*}{ Vicenin } & Control & 866.3 & 81.9 & 761.4 & 18.2 \\
\hline & F. oxysporum & $1462.4^{\star \star \star}$ & 32.8 & $1683.0^{\star \star \star}$ & 60.6 \\
\hline \multirow[t]{2}{*}{ Isoorientin } & Control & 271.6 & 9.6 & 255.4 & 8.0 \\
\hline & F. oxysporum & 258.2 & 12.7 & 268.2 & 12.4 \\
\hline \multirow[t]{2}{*}{ Vitexin } & Control & 38.0 & 1.2 & 29.0 & 27.0 \\
\hline & F. oxysporum & 36.7 & 13.2 & 37.0 & 7.0 \\
\hline \multirow[t]{2}{*}{ Isovitexin } & Control & 101.7 & 9.7 & 102.3 & 6.7 \\
\hline & F. oxysporum & 95.0 & 21.7 & $156.9^{\star \star \star}$ & 13.4 \\
\hline Quercetin & Control & 21.4 & 1.0 & 25.8 & 0.8 \\
\hline diglycoside ${ }^{\$}$ & F. oxysporum & $19.4^{\star \star}$ & 1.8 & $20.2^{*}$ & 2.0 \\
\hline Apigenin & Control & 27.2 & 1.5 & 27.1 & 0.6 \\
\hline diglycoside ${ }^{\$}$ & F. oxysporum & 21.6 & 2.1 & $24.4^{\star \star \star}$ & 2.2 \\
\hline Apigenin & Control & 216.3 & 12.5 & 164.4 & 16.4 \\
\hline diglycoside $2^{\$}$ & F. oxysporum & 207.1 & 9.1 & $227.8^{\star \star}$ & 11.1 \\
\hline \multicolumn{6}{|c|}{ CELL WALL BOUND COMPOUNDS } \\
\hline Coumaric acid & Control & 7.2 & 2.6 & 9.1 & 2.9 \\
\hline derivative $^{\$}$ & F. oxysporum & 4.6 & 1.0 & $16.6^{\star}$ & 6.7 \\
\hline
\end{tabular}

(Continued)
TABLE 2 | Continued

\begin{tabular}{|c|c|c|c|c|c|}
\hline \multirow[t]{3}{*}{ Metabolite } & & \multicolumn{4}{|c|}{ Metabolite content } \\
\hline & & \multicolumn{2}{|l|}{$24 \mathrm{~h}$} & \multicolumn{2}{|l|}{$48 \mathrm{~h}$} \\
\hline & & $\begin{array}{c}\text { mean } \\
(\mu \mathrm{g} / \mathrm{g} \mathrm{FW})\end{array}$ & $S D$ & $\begin{array}{c}\text { mean } \\
(\mu \mathrm{g} / \mathrm{g} \mathrm{FW})\end{array}$ & $S D$ \\
\hline \multirow[t]{2}{*}{ Vanillic acid } & Control & 8.3 & 0.7 & 9.7 & 1.6 \\
\hline & F. oxysporum & 8.3 & 0.6 & 9.4 & 0.4 \\
\hline 4-hydroxy- & Control & 9.5 & 1.0 & 9.4 & 0.3 \\
\hline benzaldehyde & F. oxysporum & $7.3^{*}$ & 0.6 & 9.5 & 0.5 \\
\hline \multirow[t]{2}{*}{ Vanillin } & Control & 35.1 & 6.6 & 38.8 & 1.7 \\
\hline & F. oxysporum & 30.5 & 5.4 & 38.6 & 3.4 \\
\hline \multirow[t]{2}{*}{$p$-coumaric acid } & Control & 22.6 & 2.3 & 19.2 & 3.4 \\
\hline & F. oxysporum & $13.4^{\star \star \star}$ & 1.0 & 15.5 & 1.3 \\
\hline \multirow[t]{2}{*}{ Ferulic acid } & Control & 101.5 & 5.8 & 85.7 & 10.6 \\
\hline & F. oxysporum & $64.2^{\star \star \star}$ & 3.0 & $68.4^{*}$ & 4.1 \\
\hline \multirow[t]{2}{*}{ LIGNIN } & Control & 20.9 & 1.3 & 21.3 & 0.9 \\
\hline & F. oxysporum & 18.9 & 2.9 & $17.4^{*}$ & 2.4 \\
\hline \multirow[t]{2}{*}{ CELLULOSE } & Control & 17.5 & 1.4 & 17.9 & 1.3 \\
\hline & F. oxysporum & 18.7 & 0.8 & $21.7^{\star}$ & 2.7 \\
\hline
\end{tabular}

Statistically significant differences are marked $\left(^{*}\right.$ for $p<0.05,{ }^{* *}$ for $p<0.01$ and ${ }^{* * *}$ for $p<0.001)$. Compounds marked with $\$$ are derivatives, whose concentrations are presented in equivalents of corresponding metabolites.

TABLE 3 | Area of Fusarium oxysporum growth on PDA medium supplemented with standard solutions in $0.1,0.05$, and $0.01 \mathrm{M}$ concentrations, measured at $\mathbf{4 8} \mathrm{h}$ after medium inoculation, presented as fold of the control growth (means of three biological repeats \pm standard deviations).

\begin{tabular}{lccc} 
Compound & \multicolumn{3}{c}{ Concentration } \\
\cline { 2 - 4 } & $\mathbf{0 . 1} \mathbf{~ \mathbf { M }}$ & $\mathbf{0 . 0 5} \mathbf{~ \mathbf { M }}$ & $\mathbf{0 . 0 1} \mathbf{~ m M}$ \\
\hline Salicylic acid & $1.06 \pm 0.03$ & $1.05 \pm 0.12$ & $0.98 \pm 0.05$ \\
Vanillin & $0.5 \pm 0.01^{*}$ & $0.84 \pm 0.11$ & $0.67 \pm 0.08^{*}$ \\
Vanillic acid & $0.58 \pm 0.05^{*}$ & $0.79 \pm 0.08$ & $0.64 \pm 0.04^{*}$ \\
p-coumaric acid & $0.61 \pm 0.04^{*}$ & $0.76 \pm 0.08$ & $0.6 \pm 0.09^{*}$ \\
Caffeic acid & $0.5 \pm 0.04^{*}$ & $0.76 \pm 0.1$ & $0.66 \pm 0.05^{*}$ \\
Ferulic acid & $0.45 \pm 0.1^{*}$ & $0.68 \pm 0.06$ & $0.67 \pm 0.05^{*}$ \\
Orientin & $0.86 \pm 0.15$ & $0.63 \pm 0.07^{*}$ & $0.82 \pm 0.15$ \\
Isoorientin & $0.94 \pm 0.07$ & $0.8 \pm 0.09$ & $0.84 \pm 0.16$ \\
Vitexin & $0.38 \pm 0.02^{*}$ & $0.92 \pm 0.14$ & $0.97 \pm 0.09$ \\
Isovitexin & $0.32 \pm 0.05^{*}$ & $0.86 \pm 0.23$ & $0.91 \pm 0.16$
\end{tabular}

Statistically significant differences are marked with asterisks $(p<0.05)$

was implicated (Herrera-Vásquez et al., 2015), however, we did not see ICS induction at any time point examined, but cannot rule out its participation in the flax response. In consequence, SA and/or its methylated form-MeSA would lead to the induction of lignin biosynthesis as PAL-dependent lignification 
was shown to be induced by SA and MeSA (He and Wolyn, 2005; Mandal, 2010), which is involved in plant defense signaling (Park et al., 2007), leading to SAR and among other things to induction of lignin formation (Mandal, 2010). A simplified scheme of the phenylpropanoid pathway with marked changes in the metabolite contents and transcript levels is presented in Figure 2 .

In accordance with the results, a metabolite flux between different routes of the phenylpropanoid pathway occurs at the early stages of F. oxysporum infection of flax. The destabilization of equilibrium in phenolic biosynthesis leads to the induction of the plant response, which is most important in the earliest stages of the infection-defense signal preparation (SA, MeSA), redirection of substrates and activation/deactivation of particular metabolic routes, production of antioxidants, which are important regulators of ROS level. Restitution of cell wall integrity (lignin) occurs probably at subsequent steps of the plant's response. Induction of $P A L$ and $\beta$ ketothiolase genes suggests that in Fusarium-infected flax the biosynthesis of salicylic acid (SA) is performed mainly via the PAL-dependent route. As we observed no statistically significant increase in ICS gene transcript level at $48 \mathrm{~h}$ after infection (Supplementary Figure S1), it is possible that this route is activated at the later stages of the plant response.

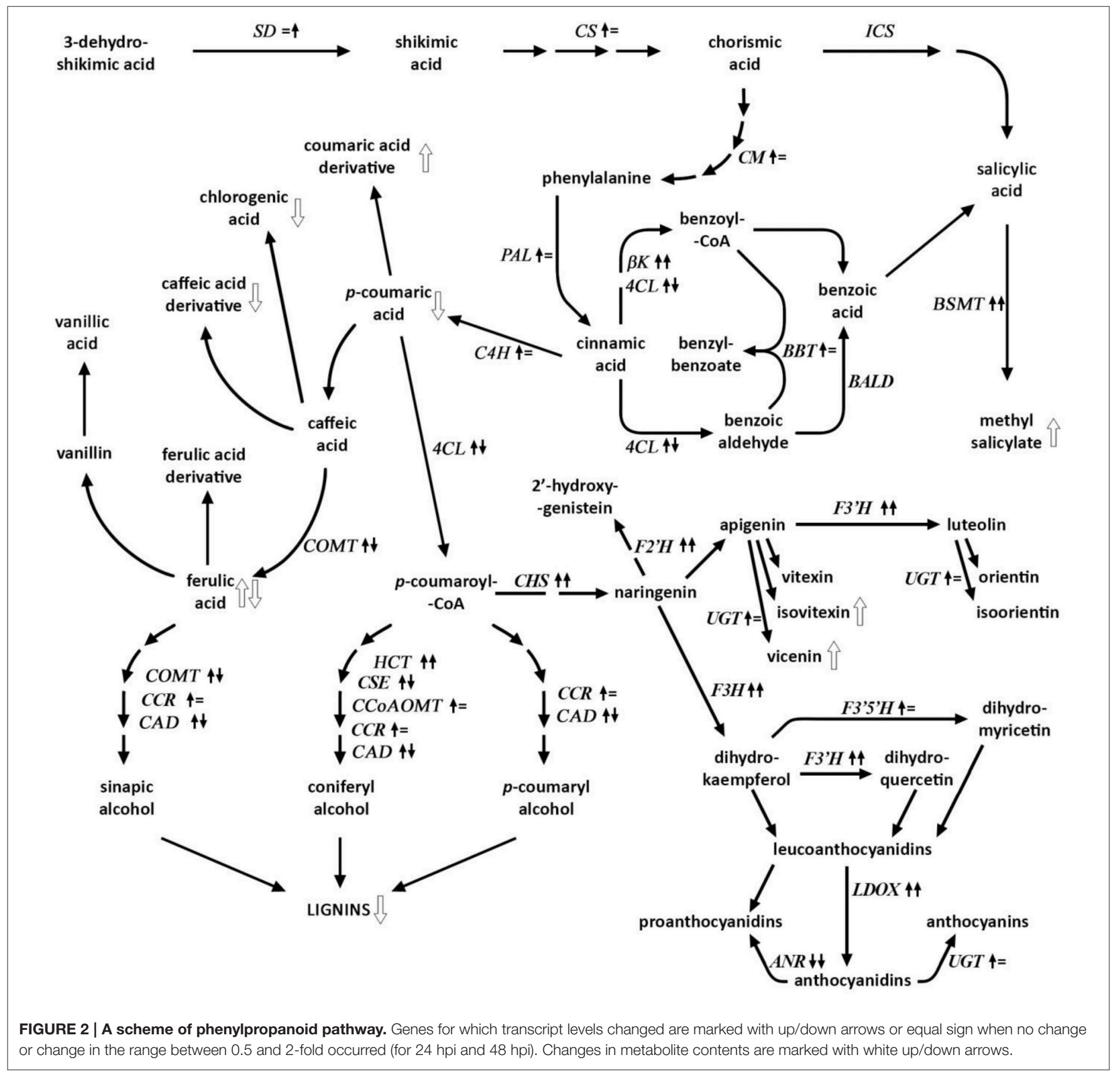


Confirmation of this suggestion requires, however, further studies involving gene knock-out experiments or specific inhibitors. Moreover, future studies should be focused on determining whether and to what extent manipulation of a redundant or adverse metabolic route within a pathway will favor other, advantageous ones.

\section{AUTHOR CONTRIBUTIONS}

$\mathrm{AB}$ performed infection tests and gene expression analysis, participated in RNAseq analysis. KK performed metabolite analysis and wrote the manuscript. AKo investigated the influence of phenolics to fungal growth, participated in writing the manuscript. WW performed gene expression analysis. MD performed GC-MS analysis. MP participated in RNAseq analysis. JS coordinated the study, participated in data analysis.

\section{REFERENCES}

Wildermuth, M. C., Dewdney, J., Wu, G., and Ausubel, F. M. (2001). Isochorismate synthase is required to synthesize salicylic acid for plant defence. Nature 414, 562-565. doi: $10.1038 / 35107108$

Ali, G. S., and Reddy, A. S. N. (2008). PAMP-triggered immunity: early events in the activation of FLAGELLIN SENSITIVE2. Plant Signal. Behav. 3, 423-426. doi: 10.4161/psb.3.6.5472

Besseau, S., Hoffmann, L., Geoffroy, P., Lapierre, C., Pollet, B., and Legrand, M. (2007). Flavonoid accumulation in arabidopsis repressed in lignin synthesis affects auxin transport and plant growth. Plant Cell 19, 148-162. doi: 10.1105/tpc. 106.044495

Bonnemain, J. L., Chollet, J. F., and Rocher, F. (2013). "Transport of salicylic acid and related compounds," in SALICYLIC ACID: Plant Growth and Development, eds S. Hayat, A. Ahmad, and M. N. Alyemeni (Dordrecht: Springer Netherlands), 43-59.

Boutigny, A. L., Barreau, C., Atanasova-Penichon, V., Verdal-Bonnin, M. N., Pinson-Gadais, L., and Richard-Forget, F. (2009). Ferulic acid, an efficient inhibitor of type $B$ trichothecene biosynthesis and Tri gene expression in Fusarium liquid cultures. Mycol. Res. 113(Pt 6-7), 746-753. doi: 10.1016/j.mycres.2009.02.010

Chen, F., D’Auria, J. C., Tholl, D., Ross, J. R., Gershenzon, J., Noel, J. P., et al. (2003). An Arabidopsis thaliana gene for methylsalicylate biosynthesis, identified by a biochemical genomics approach, has a role in defense. Plant J. 36, 577-588. doi: 10.1046/j.1365-313X.2003.01902.x

Chen, Z., Zheng, Z., Huang, J., Lai, Z., and Fan, B. (2009). Biosynthesis of salicylic acid in plants. Plant Signal. Behav. 4, 493-496. doi: 10.4161/psb.4.6.8392

Daayf, F., El Hadrami, A., El-Bebany, A. F., Henriquez, M. A., Yao, Z., Derksen, H., et al. (2012). "Phenolic compounds in plant defense and pathogen counterdefense mechanisms," in Recent Advances in Polyphenol Research, eds V. Cheynier, P. Sarni-Manchado, and S. Quideau (Oxford: Wiley-Blackwell), 191-208.

Dai, J., and Mumper, R. J. (2010). Plant phenolics: extraction, analysis and their antioxidant and anticancer properties. Molecules 15, 7313-7352. doi: 10.3390/molecules 15107313

Davis, K. R., and Hahlbrock, K. (1987). Induction of defense responses in cultured parsley cells by plant cell wall fragments. Plant Physiol. 84, 1286-1290. doi: $10.1104 /$ pp.84.4.1286

Dempsey, D. M. A., Vlot, A. C., Wildermuth, M. C., and Klessig, D. F. (2011). Salicylic acid biosynthesis and metabolism. Arabidopsis Book 9:e0156. doi: 10.1199/tab.0156

Ferrochio, L., Cendoya, E., Farnochi, M. C., Massad, W., and Ramirez, M. L. (2013). Evaluation of ability of ferulic acid to control growth and fumonisin production of Fusarium verticillioides and Fusarium proliferatum on maize based media. Int. J. Food Microbiol. 167, 215-220. doi: 10.1016/j.ijfoodmicro.2013.09.005

Field, B., Jordan, F., and Osbourn, A. (2006). First encountersdeployment of defence-related natural products by plants.
$\mathrm{AKu}$ planned the experiments and participated in writing the manuscript.

\section{ACKNOWLEDGMENTS}

This study was supported by grant No. 2013/11/B/NZ1/00007, 2014/15/B/NZ9/00470 from the National Science Centre (NCN, Poland) and Wroclaw Centre of Biotechnology, The Leading National Research Centre (KNOW) programme for the years 2014-2018.

\section{SUPPLEMENTARY MATERIAL}

The Supplementary Material for this article can be found online at: http://journal.frontiersin.org/article/10.3389/fpls.2016. 01951/full\#supplementary-material Gallego-Giraldo, L., Escamilla-Trevino, L., Jackson, L. A., and Dixon, R. A. (2011b). Salicylic acid mediates the reduced growth of lignin down-regulated plants. Proc. Natl. Acad. Sci. U.S.A. 108, 20814-20819. doi: 10.1073/pnas.1117873108

Gallego-Giraldo, L., Jikumaru, Y., Kamiya, Y., Tang, Y., and Dixon, R. A. (2011a). Selective lignin downregulation leads to constitutive defense response expression in alfalfa (Medicago sativa L.). New Phytol. 190, 627-639. doi: 10.1111/j.1469-8137.2010.03621.x

Garcion, C., Lohmann, A., Lamodière, E., Catinot, J., Buchala, A., Doermann, P., et al.Métraux, P. (2008). Characterization and biological function of the ISOCHORISMATE SYNTHASE2 gene of arabidopsis. Plant Physiol. 147, 1279-1287. doi: 10.1104/pp.108.119420

Govrin, E. M., and Levine, A. (2000). The hypersensitive response facilitates plant infection by the necrotrophic pathogen Botrytis cinerea. Curr. Biol. 10, 751-757. doi: 10.1016/S0960-9822(00)00560-1

Hano, C., Addi, M., Bensaddek, L., Cronier, D., Baltora-Rosset, S., Doussot, J., et al. (2006). Differential accumulation of monolignol-derived compounds in elicited flax (Linum usitatissimum) cell suspension cultures. Planta 223, 975-989. doi: 10.1007/s00425-005-0156-1

Hatfield, R. (2001). Lignin formation in plants. the dilemma of linkage specificity. Plant Physiol. 126, 1351-1357. doi: 10.1104/pp.126.4.1351

He, C. Y., and Wolyn, D. J. (2005). Potential role for salicylic acid in induced resistance of asparagus roots to Fusarium oxysporum f.sp. asparagi. Plant Pathol. 54, 227-232. doi: 10.1111/j.1365-3059.2005.01163.x

Heller, K., Andruszewska, A., Grabowska, L., and Wielgusz, K. (2006). Ochrona lnu i konopi w Polsce i na Świecie. Prog. Plant Prot. 46, 88-98. Available online at: https://www.researchgate.net/publication/242397949_ochrona_lnu_ i_konopi_w_polsce_i_na_swiecie

Herrera-Vásquez, A., Salinas, P., and Holuigue, L. (2015). Salicylic acid and reactive oxygen species interplay in the transcriptional control of defense genes expression. Front. Plant Sci. 6:171. doi: 10.3389/fpls.2015.00171

Huang, J., Gu, M., Lai, Z., Fan, B., Shi, K., Zhou, Y.-H, et al. (2010). Functional analysis of the Arabidopsis PAL gene family in plant growth, development, and response to environmental stress. Plant Physiol. 153, 1526-1538. doi: 10.1104/pp.110.157370

Huang, Z.-H., Wang, Z.-L., Shi, B.-L., Wei, D., Chen, J.-X., Wang, S.-I, et al. (2015) Simultaneous determination of salicylic acid, jasmonic acid, methyl salicylate, and methyl jasmonate from Ulmus pumila leaves by GC-MS. Int. J. Anal. Chem. 2015:7. doi: $10.1155 / 2015 / 698630$

Iiyama, K., and Wallis, A. F. A. (1990). Determination of lignin in herbaceous plants by an improved acetyl bromide procedure. J. Sci. Food Agric. 51, 145-161. doi: $10.1002 /$ jsfa. 2740510202

Khanam, U. K. S., Oba, S., Yanase, E., and Murakami, Y. (2012). Phenolic acids, flavonoids and total antioxidant capacity of selected leafy vegetables. J. Funct. Foods 4, 979-987. doi: 10.1016/j.jff.2012.07.006 
Klempien, A., Kaminaga, Y., Qualley, A., Nagegowda, D. A., Widhalm, J. R., Orlova, I., et al. (2012). Contribution of CoA ligases to benzenoid biosynthesis in petunia flowers. Plant Cell 24, 2015-2030. doi: 10.1105/tpc.112. 097519

Kocacaliskan, I., Talan, I., and Terzi, I. (2006). Antimicrobial activity of catechol and pyrogallol as allelochemicals. Z. Naturforsch. C 61, 639-642. doi: 10.1515/znc-2006-9-1004

Korkina, L. G. (2007). Phenylpropanoids as naturally occurring antioxidants: from plant defense to human health. Cell. Mol. Biol. (Noisy-le-grand) 53, 15-25. doi: $10.1170 / \mathrm{T} 772$

Kostyn, K., Czemplik, M., Kulma, A., Bortniczuk, M., Skała, J., and Szopa, J. (2012). Genes of phenylpropanoid pathway are activated in early response to Fusarium attack in flax plants. Plant Sci. 190, 103-115. doi: 10.1016/j.plantsci.2012.03.011

Krol, P., Igielski, R., Pollmann, S., and Kepczynska, E. (2015). Priming of seeds with methyl jasmonate induced resistance to hemi-biotroph Fusarium oxysporum f.sp. lycopersici in tomato via 12-oxo-phytodienoic acid, salicylic acid, and flavonol accumulation. J. Plant Physiol. 179, 122-132. doi: 10.1016/j.jplph.2015.01.018

Laffont, C., Blanchet, S., Lapierre, C., Brocard, L., Ratet, P., Crespi, M., et al. (2010). The compact root architecturel gene regulates lignification, flavonoid production, and polar auxin transport in Medicago truncatula. Plant Physiol. 153, 1597-1607. doi: 10.1104/pp.110.156620

Lattanzio, V., Lattanzio, V. M. T., and Cardinali, A. (2006). "Role of phenolics in the resistance mechanisms of plants against fungal pathogens and insects," in Phytochemistry: Advances in Research, ed F. Imperato (Trivandrum: Research Signpost), 23-67.

Lawton, M. A., and Lamb, C. J. (1987). Transcriptional activation of plant defense genes by fungal elicitor, wounding, and infection. Mol. Cell. Biol. 7, 335-341. doi: 10.1128/MCB.7.1.335

Lazar, T. (2005). Biochemistry and molecular and biology of plants B. Buchanan, W. Gruissem, and R. L. Jones (eds), American Society of Plant Physiologists (distribution through Wiley \& Sons), xxxix + 1367 pp., $\leq 100$ (\$175), ISBN 0943088-37-2 (hardback); $\leq 75$ (\$135), ISBN 0-943088-39-9 (paperback) (2002). Cell Biochem. Funct. 23, 148-148. doi: 10.1002/cbf.1131

Lehmann, S., Serrano, M., L'Haridon, F., Tjamos, S. E., and Metraux, J. P. (2015). Reactive oxygen species and plant resistance to fungal pathogens. Phytochemistry 112, 54-62. doi: 10.1016/j.phytochem.2014.08.027

Li, X., Bonawitz, N. D., Weng, J. K., and Chapple, C. (2010). The growth reduction associated with repressed lignin biosynthesis in Arabidopsis thaliana is independent of flavonoids. Plant Cell 22, 1620-1632. doi: $10.1105 /$ tpc. 110.074161

Lorenc-Kukula, K., Zuk, M., Kulma, A., Czemplik, M., Kostyn, K., Skala, J., et al. (2009). Engineering flax with the GT family 1 Solanum sogarandinum glycosyltransferase SsGT1 confers increased resistance to Fusarium infection. J. Agric. Food Chem. 57, 6698-6705. doi: 10.1021/jf900833k

Mammarella, N. D., Cheng, Z., Fu, Z. Q., Daudi, A., Bolwell, G. P., Dong, $X$., et al. (2015). Apoplastic peroxidases are required for salicylic acidmediated defense against Pseudomonas syringae. Phytochemistry 112, 110-121. doi: 10.1016/j.phytochem.2014.07.010

Mandal, S. (2010). Induction of phenolics, lignin and key defense enzymes in eggplant (Solanum melongena L.) roots in response to elicitors. Afr. J. Biotechnol. 9, 8038-8047. doi: 10.5897/AJB10.984

Mandal, S., Das, R. K., and Mishra, S. (2011). Differential occurrence of oxidative burst and antioxidative mechanism in compatible and incompatible interactions of Solanum lycopersicum and Ralstonia solanacearum. Plant Physiol. Biochem. 49, 117-123. doi: 10.1016/j.plaphy.2010.10.006

Mandal, S., Mallick, N., and Mitra, A. (2009). Salicylic acid-induced resistance to Fusarium oxysporum f. sp lycopersici in tomato. Plant Physiol. Biochem. 47, 642-649. doi: 10.1016/j.plaphy.2009.03.001

Michielse, C. B., and Rep, M. (2009). Pathogen profile update: Fusarium oxysporum. Mol. Plant Pathol. 10, 311-324. doi: 10.1111/j.1364-3703.2009. 00538.x

Mierziak, J., Kostyn, K., and Kulma, A. (2014a). Flavonoids as important molecules of plant interactions with the environment. Molecules 19, 16240-16265. doi: 10.3390/molecules 191016240

Mierziak, J., Wojtasik, W., Kostyn, K., Czuj, T., Szopa, J., and Kulma, A. (2014b). Crossbreeding of transgenic flax plants overproducing flavonoids and glucosyltransferase results in progeny with improved antifungal and antioxidative properties. Mol. Breeding 34, 1917-1932. doi: $10.1007 / \mathrm{s} 11032-014-0149-5$
Muir, A. D., and Westcott, D. N. (eds.). (2003). Flax: The Genus Linum. Saskatchewan: Taylor and Francis.

Muthamilarasan, M., and Prasad, M. (2013). Plant innate immunity: an updated insight into defense mechanism. J. Biosci. 38, 433-449. doi: 10.1007/s12038-013-9302-2

O’Brien, J. A., Daudi, A., Finch, P., Butt, V. S., Whitelegge, J. P., Souda, P., et al. (2012). A peroxidase-dependent apoplastic oxidative burst in cultured Arabidopsis cells functions in MAMP-elicited defense. Plant Physiol. 158, 2013-2027. doi: 10.1104/pp.111.190140

Olivain, C., Trouvelot, S., Binet, M. N., Cordier, C., Pugin, A., and Alabouvette, C. (2003). Colonization of flax roots and early physiological responses of flax cells inoculated with pathogenic and nonpathogenic strains of Fusarium oxysporum. Appl. Environ. Microbiol. 69, 5453-5462. doi: 10.1128/AEM.69.9.5453-5462.2003

Park, S. W., Kaimoyo, E., Kumar, D., Mosher, S., and Klessig, D. F. (2007). Methyl salicylate is a critical mobile signal for plant systemic acquired resistance. Science 318, 113-116. doi: 10.1126/science.1147113

Rodriguez, A., Perestelo, F., Carnicero, A., Regalado, V., Perez, R., De la Fuente, G., et al. (1996). Degradation of natural lignins and lignocellulosic substrates by soil-inhabiting fungi imperfecti. FEMS Microbiol. Ecol. 21, 213-219. doi: 10.1111/j.1574-6941.1996.tb00348.x

Russell, P., Hertz, P., and McMillan, B. (2016). Biology: The Dynamic Science, Vol. 3. Boston, MA: Cengage Learning.

Sharma, P., Jha, A. B., Dubey, R. S., and Pessarakli, M. (2012). Reactive oxygen species, oxidative damage, and antioxidative defense mechanism in plants under stressful conditions. J. Bot. 2012:26. doi: 10.1155/2012/217037

Shin, S., Torres-Acosta, J. A., Heinen, S. J., McCormick, S., Lemmens, M., Paris, M. P., et al. (2012). Transgenic Arabidopsis thaliana expressing a barley UDPglucosyltransferase exhibit resistance to the mycotoxin deoxynivalenol. J. Exp. Bot. 63, 4731-4740. doi: 10.1093/jxb/ers141

Stafford, H. (1974). Possible multienzyme complexes regulating the formation of C6-C3 phenolic compounds and lignins in higher plants. Rec. Adv. Phytochem. 8, 53-79. doi: 10.1016/b978-0-12-612408-8.50009-3

Tsuda, K., Sato, M., Glazebrook, J., Cohen, J. D., and Katagiri, F. (2008). Interplay between MAMP-triggered and SA-mediated defense responses. Plant J. 53, 763-775. doi: 10.1111/j.1365-313X.2007.03369.x

Velika, B., and Kron, I. (2012). Antioxidant properties of benzoic acid derivatives against Superoxide radical. Free Radic. Antioxidants 2, 62-67. doi: 10.5530/ax.2012.4.11

Ververis, C., Georghiou, K., Christodoulakis, N., Santas, P., and Santas, R. (2004). Fiber dimensions, lignin and cellulose content of various plant materials and their suitability for paper production. Ind. Crops Prod. 19, 245-254. doi: $10.1016 /$ j.indcrop.2003.10.006

Vlot, A. C., Dempsey, D. A., and Klessig, D. F. (2009). Salicylic Acid, a multifaceted hormone to combat disease. Annu. Rev. Phytopathol. 47, 177-206. doi: 10.1146/annurev.phyto.050908.135202

Widhalm, J. R., and Dudareva, N. (2015). A familiar ring to it: biosynthesis of plant benzoic acids. Mol. Plant 8, 83-97. doi: 10.1016/j.molp.2014.12.001

Xue, R. F., Wu, J., Wang, L. F., Blair, M. W., Wang, X. M., Ge, W. D., et al. (2014). Salicylic acid enhances resistance to Fusarium oxysporum f. sp. phaseoli in common beans (Phaseolus vulgaris L.). J. Plant Growth Regul. 33, 470-476. doi: 10.1007/s00344-013-9376-y

Zipfel, C., and Robatzek, S. (2010). Pathogen-associated molecular pattern-triggered immunity: veni, vidi...? Plant Physiol. 154, 551-554. doi: 10.1104/pp.110.161547

Zuk, M., Kulma, A., Dyminska, L., Szoltysek, K., Prescha, A., Hanuza, J., et al. (2011). Flavonoid engineering of flax potentiate its biotechnological application. BMC Biotechnol. 11:10. doi: 10.1186/1472-6750-11-10

Conflict of Interest Statement: The authors declare that the research was conducted in the absence of any commercial or financial relationships that could be construed as a potential conflict of interest.

Copyright (๑) 2017 Boba, Kostyn, Kostyn, Wojtasik, Dziadas, Preisner, Szopa and Kulma. This is an open-access article distributed under the terms of the Creative Commons Attribution License (CC BY). The use, distribution or reproduction in other forums is permitted, provided the original author(s) or licensor are credited and that the original publication in this journal is cited, in accordance with accepted academic practice. No use, distribution or reproduction is permitted which does not comply with these terms. 